石油技術協会誌 第 81 巻 第 6 号 (平成 28 年 11 月) $479 \sim 488$ 頁

Journal of the Japanese Association for Petroleum Technology

Vol. 81, No. 6 (Nov., 2016) pp. 479 488

\begin{tabular}{l}
\hline 講 演 \\
Lecture
\end{tabular}

\title{
Fracture optimization study in the Montney tight sand play*
}

\author{
Kotaro Sekine $^{* *, \dagger}$, Chandresh Singh ${ }^{* * *}$ and Shoji Hara ${ }^{* * * *}$
}

(Received September 16, 2016 ; accepted November 7, 2016)

\begin{abstract}
Encana Corporation has employed several completion techniques over the past decade to successfully develop the unconventional Montney tight gas reservoir. Optimizing fracture stimulation and design has been an important focus for improving productivity and overall well economics. This paper outlines several factors that could influence hydraulic fracture propagation behaviour in the Upper Montney formation. Commercial fracture modeling software and microseismic surveys were used to improve understanding of fracture geometry and propagation. Sensitivities around elastic moduli, closure pressure, pore pressure and composite layering were used to highlight the range of possible geometries. This study revealed several potential fracture barriers in the Montney package which could impede vertical fracture growth. Production data was also investigated for the selected wells to examine the relationship between frac size, fluid volume, and productivity. Production analysis revealed that cumulative gas production has a linear relationship with injected water volume and the gradient of the least squares fitted line to the relationship varies by target zone. Increasing injection volume twice increased cumulative gas production by 1.81 time. Fracture modeling suggested that increased fracture surface area may be one possible explanation for increased productivity for the Upper Montney 1 zone in this study area.
\end{abstract}

Keywords : multistage fracturing, Montney tight gas play, fracture modeling, slick water fracturing

\section{Introduction}

The Triassic Montney formation is one of the most promising productive unconventional resource plays in North America and is located across the border between the British Columbia and Alberta (Fig. 1). The unconventional play has been developed by application of drilling horizontal wells and completing them using multistage hydraulic fracturing. Understanding hydraulic fracture propagation behaviour is of considerable importance as it improves an operator's ability to increase hydrocarbon resource from low permeability reservoirs in an economic manner and is key for optimizing landing horizons, well spacing, stage spacing and lateral length.

Encana Corporation, Mitsubishi Corporation and JOGMEC have been working collaboratively since 2014 to conduct geomechanical research into the Montney tight gas play located in the Dawson Creek area. Estimations of

\footnotetext{
* 平成 28 年 6 月 9 日, 平成 28 年度春季講演会開発・生産部門シンポ ジウム「変わりゆく開発環境下での油ガス田操業最適化シンポジウ ム」にて講演 2016 JAPT Development and Production Technology Symposium entitled "Optimized Field Operations to Overcome the Harsh E\&P Environment” held in Akita Japan on June 9, 2016.

** (独) 石油天然ガス・金属鉱物資源機構 JOGMEC

*** エンカナ社 Encana Corporation

**** 三菱商事株式会社 Mitsubishi Corporation

† Corresponding author : E-Mail : sekine-kotaro@jogmec.go.jp
}

geomechanical properties and petrophysical characteristics were conducted through examinations of regional stresses, $\log$ interpretations and mechanical testing on the local core samples in conjunction with investigating seismic data. Variations of stress magnitudes and mechanical properties against depth (stress and mechanical models) were prepared in the previous study.

In this manuscript we will describe the attempt to understand hydraulic fracture propagation behavior in the Upper Montney formation located in the northern section of Dawson Creek through the production data review, microseismic studies and fracture modeling using the calibrated stress and mechanical models.

\section{Geological settings and study area}

The Montney is an unconventional formation up to 300 meters thick with changing vertical and horizontal geological properties. The formation is classified as siliciclastic sediments and divided into Upper and Lower Montney formations having different geological origins (Davies, 1997). The Upper Montney formation is proximal coarse sediment and in contrast the Lower Montney formation has deeper depositional environment with more distal fine sediment (Fig. 2). The formation is further divided into subgroups named A, B1, B2 and so on and horizontal drilling and multistage fracturing have been adapted by target zones comprised of 


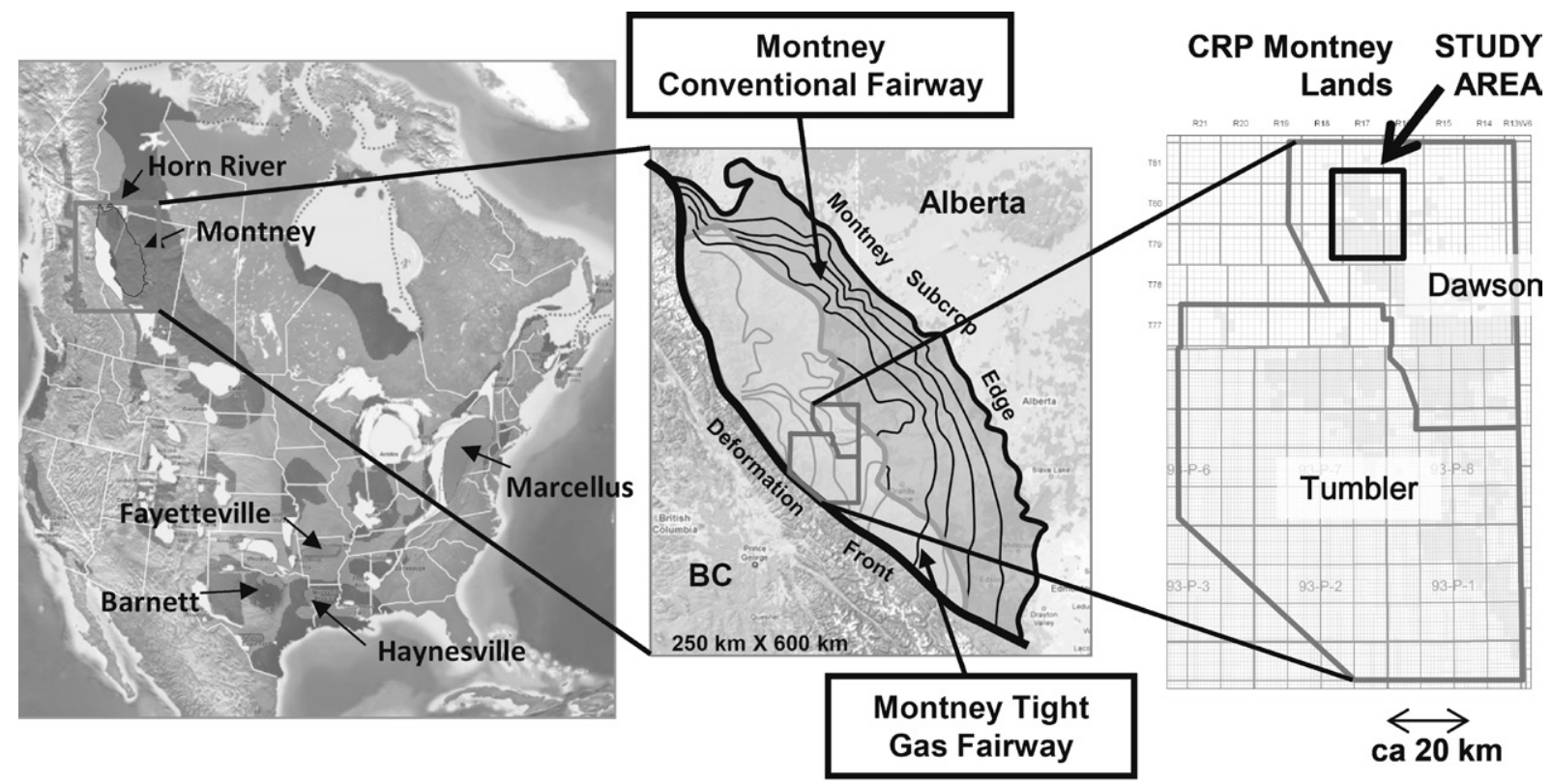

Fig. 1 Geographic location of the Montney tight gas play (left and middle) and location of the study area (right)

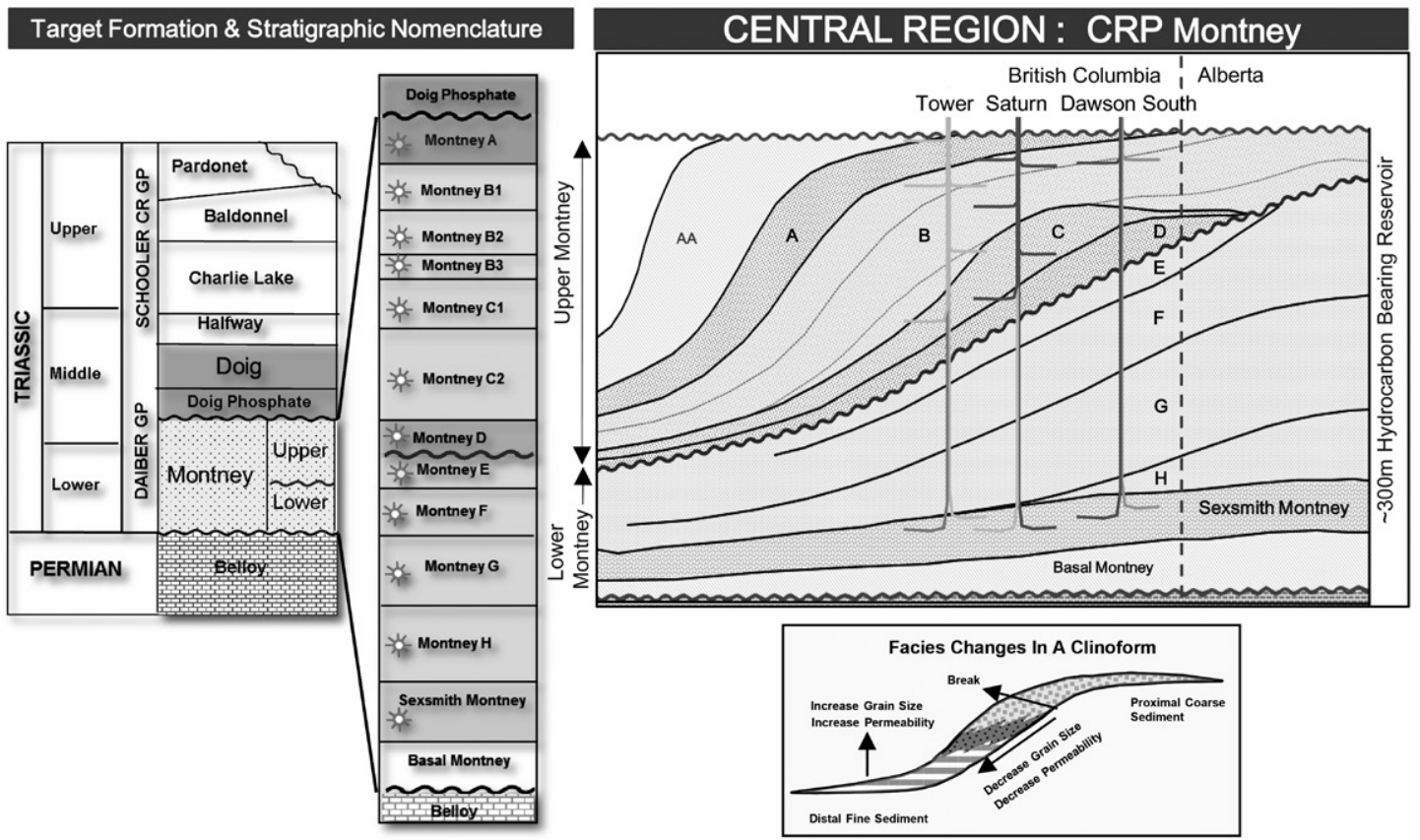

Fig. 2 Cross section showing target formation and stratigraphic classification in the Montney formation

the several subgroups. Producing gas characteristic varies by area. Dawson north (Saturn) area, which is our study area (Fig. 1), is located in a condensate rich area. This study focuses primarily on hydraulic fracture behavior for the Upper Montney formation, especially for the Upper Montney 1 zone as described later.

\section{Evolution of Montney Completion design}

A typical well for the area is a two string design having a surface casing $(219.1 \mathrm{~mm})$ to base of groundwater, a production casing $(114.3 \mathrm{~mm})$ run to the zone of interest and cemented to surface. Standard lateral lengths can range from $2,500-3,000 \mathrm{~m}$ and are completed with up to 30 frac stages.
Various types of fracture stimulation designs have been tested to develop the Montney unconventional tight gas play (Fig. 3). While energized foam fracturing techniques were adapted during the early stages of field development, slick water fracturing has been a recent trend starting in 2012 during the time when Mitsubishi Corporation acquired interest as part of the Cutbank Ridge Partnership (CRP). Efforts to optimize the current completion design are ongoing process with recent pilot sensitivities focused around frac size and stage spacing. Although it is understood that created fracture geometry for the different horizons is variable in nature, these recent studies have been successful in demonstrating a successful trend towards higher initial production. Recent analysis has 


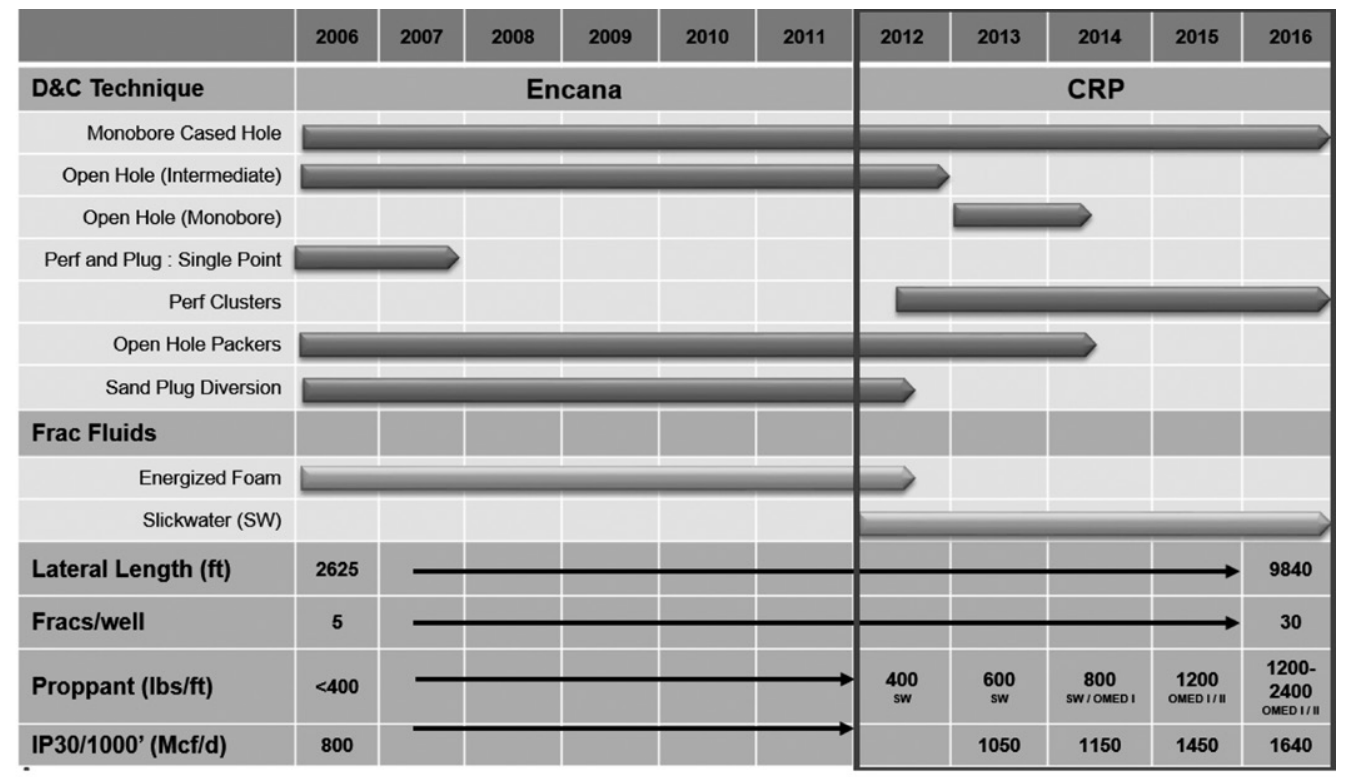

Fig. 3 Evolution of the completion design

(a)

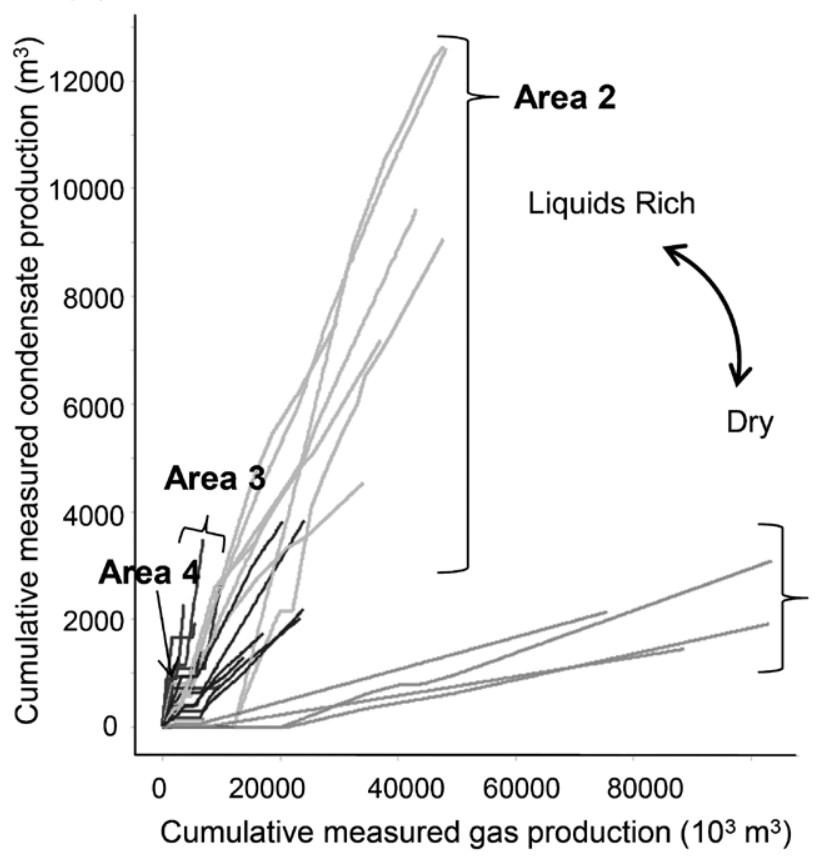

(b)

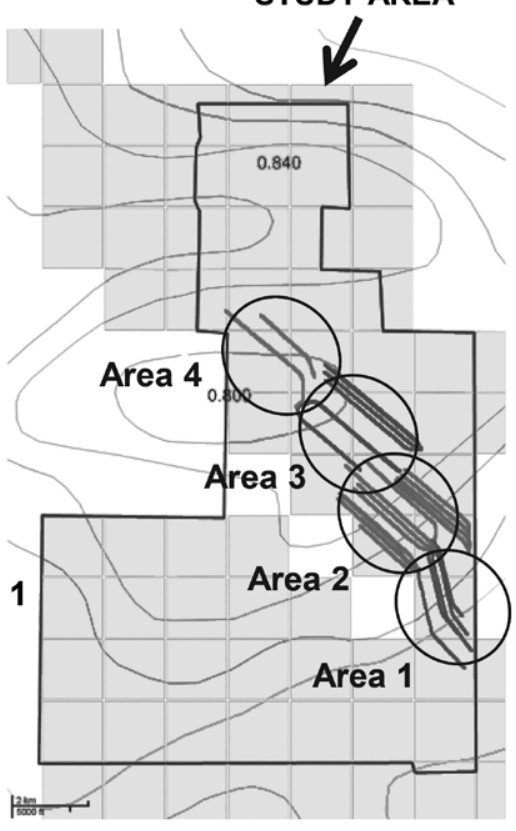

Fig. 4 (a) Cumulative gas and condensate production of the selected wells in the study area. (b) Well location for the selected wells.

suggested that despite higher initial production rates, longer term production is required to establish if there is an increase in ultimate hydrocarbon recovery.

In order to justify changes to the fracture design pertaining to job size, it should be demonstrated that the additional proppant laden fluid effectively creates new hydraulic fractures. The following sections will describe field evidence that was used to constrain and calibrate the fracture model and improve our understanding of fracture propagation behavior within the Upper Montney formation.

\section{Production data review for the study area}

In the study area, condensate-gas ratio (CGR) varies significantly by area. Fig. 4a indicates cumulative gas and condensate production for the selected wells in the study area. The wells are divided by 4 areas to have similar CGR trend for representation purposes (Fig. 4b).

A clear trend in CGR is visible with wells in the South-East region having lower condensate yields (dry) when compared against those in the North-West regions (liquids rich). Most 

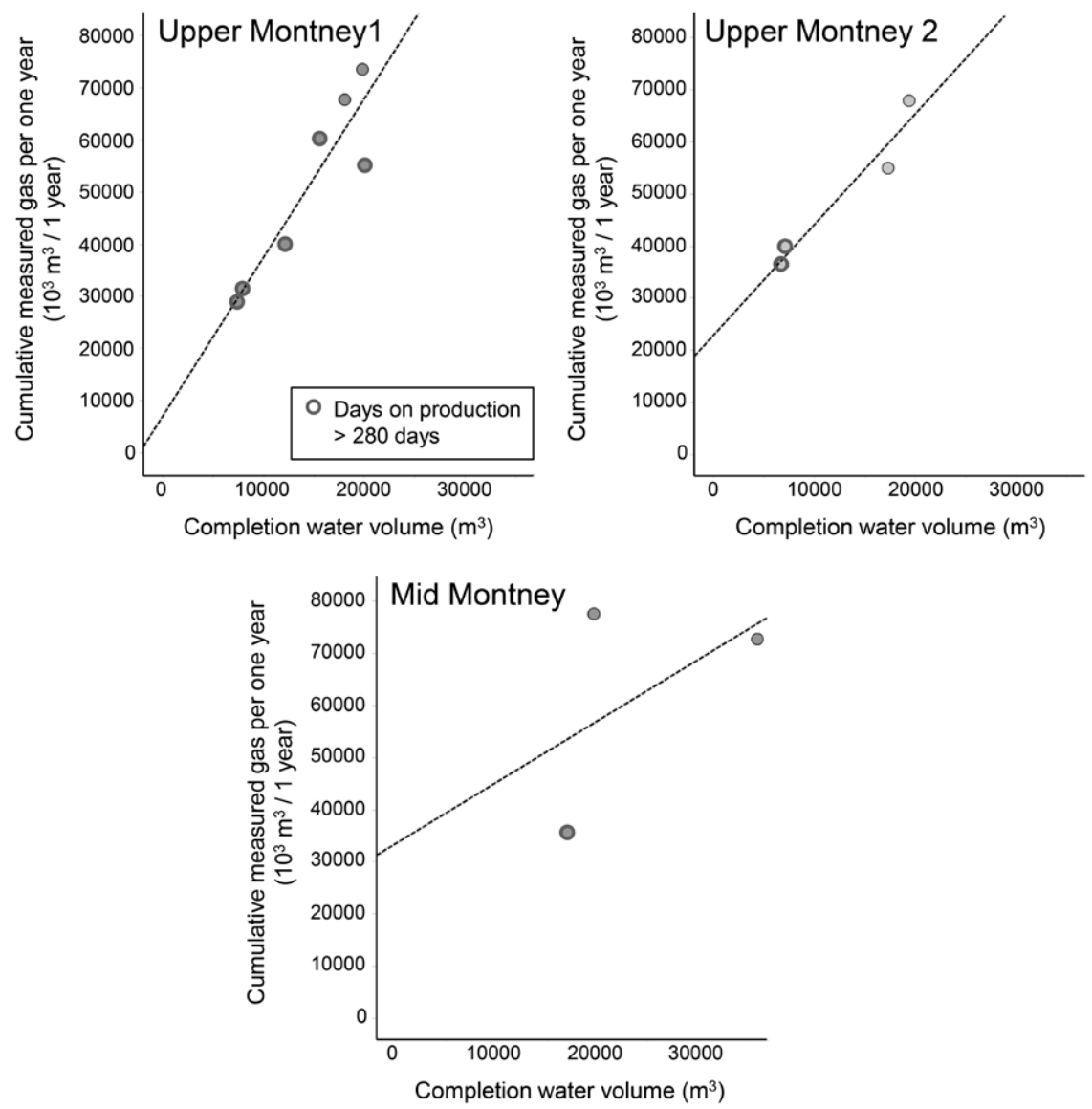

Fig. 5 Relationship between completion water volume and cumulative measure gas per one year by target zones.

Table 1 Gains in production by different target zones when job size is doubled

\begin{tabular}{c|c|c|c|c|c}
\hline \multicolumn{2}{c|}{ Upper Montney 1 } & \multicolumn{2}{c|}{ Upper Montney 2 } & \multicolumn{2}{c}{ Mid Montney } \\
\hline $\begin{array}{c}\text { Water volume } \\
\left(\mathrm{m}^{3}\right)\end{array}$ & $\begin{array}{c}\text { Gain in } \\
\text { production } \\
(-)\end{array}$ & $\begin{array}{c}\text { Water volume } \\
\left(\mathrm{m}^{3}\right)\end{array}$ & $\begin{array}{c}\text { Gain in } \\
\text { production } \\
(-)\end{array}$ & $\begin{array}{c}\text { Water volume } \\
\left(\mathrm{m}^{3}\right)\end{array}$ & $\begin{array}{c}\text { Gain in } \\
\text { production } \\
(-)\end{array}$ \\
\hline 10000 & 1 & 10000 & 1 & 10000 & 1 \\
20000 & 1.81 & 20000 & 1.48 & 20000 & 1.26 \\
\hline
\end{tabular}

(a)

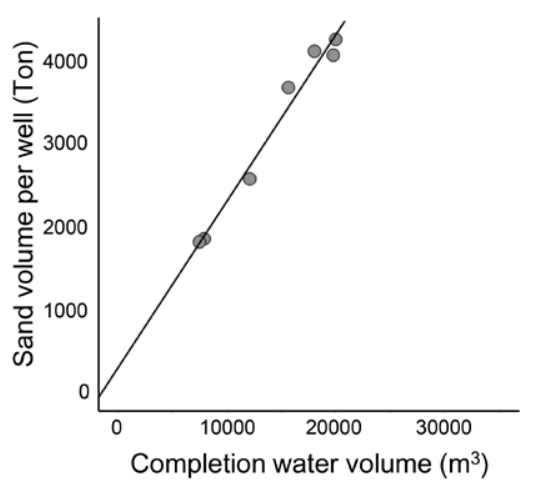

(b)

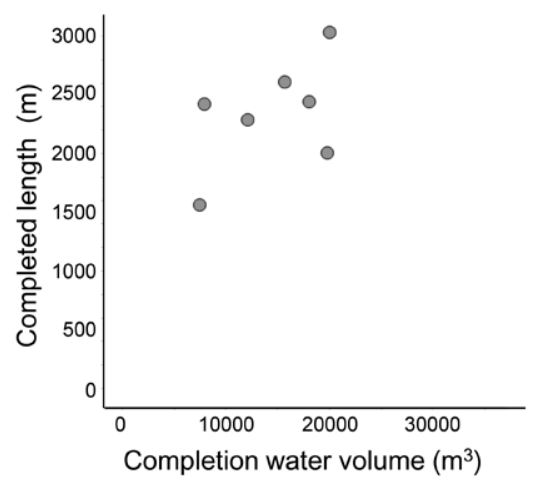

Fig. 6 (a) relationship between sand volume and completion water volume and relationship between completion length and completion water volume for the wells landing the Upper Montney 1 in the area 2.

of the wells penetrate target zones of the Upper Montney 1 and 2 therefore CGR trends are a good representation of fluid character for the Upper Montney formation. This type of characterization based on CGR trends was used to filter and combine wells having similar and comparable reservoir characteristics. Wells in Area 2 have comparable CGR trends 


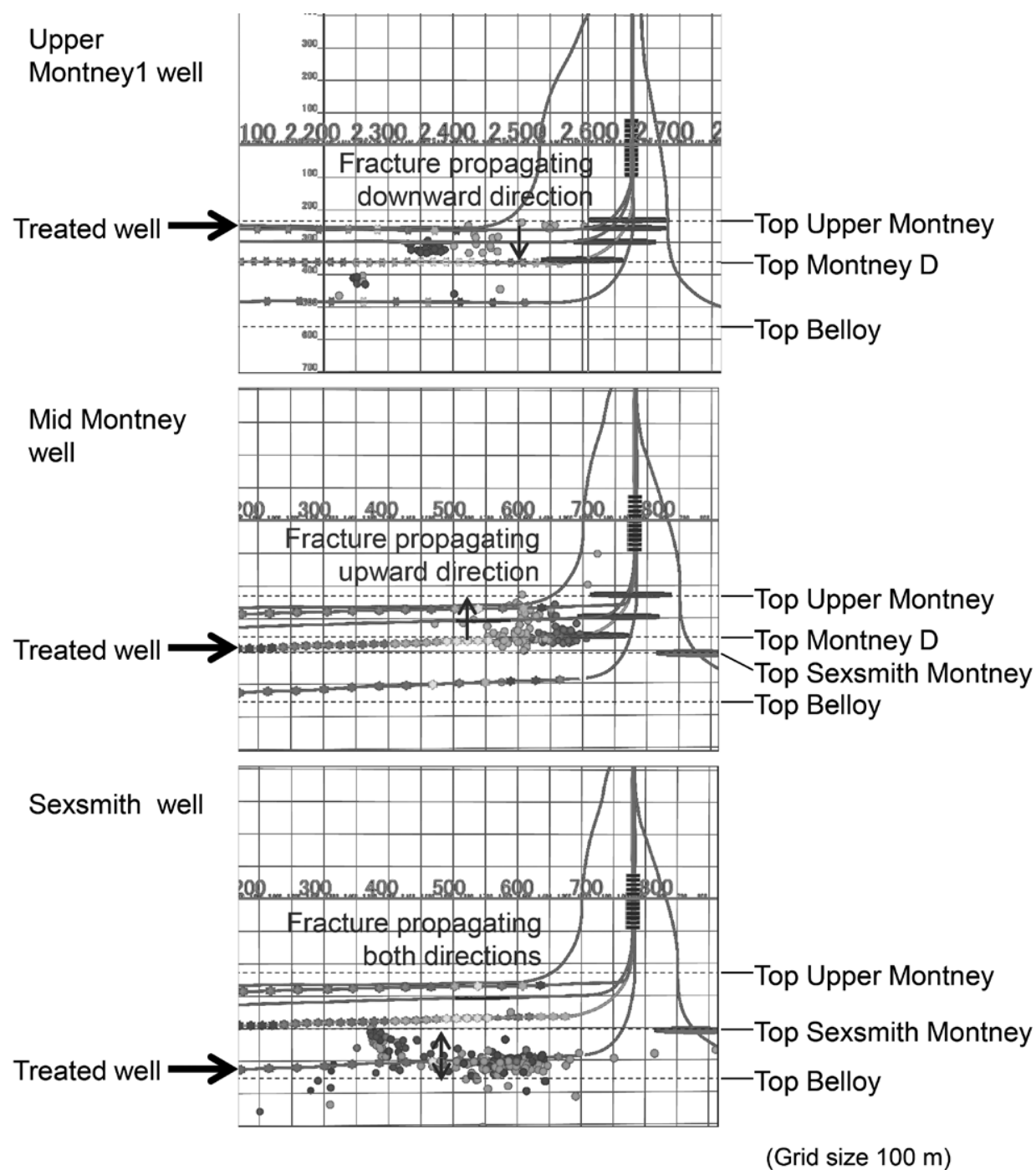

Fig. 7 Cross section indicating fracture propagation by the three different target depths

and were used to investigate the influence of job size to gas productivity.

The relationship between volume of water pumped during the completion phase per well and cumulative measured gas per one year from the initial production was investigated for different target zones of the Upper Montney 1, 2 and Mid Montney in Area 2 (Fig. 5).

Note that the days on production varies by wells, 8 out of 14 examined wells have days on production more than 280 days and other wells have short production history around the 100 days. Cumulative measured gas adopted in the vertical axis are normalized values which are obtained by linear extrapolation for the well with days on production less than one year. Plots highlighted by bold line denote wells with more than 280 days on production.

Both the Upper Montney 1 and 2 wells exhibit clear linear relationship between completion water volume and cumulative measured gas production per one year. For the Mid Montney wells there is scatter which may be influenced by a lack of representative data points. Assuming a completion water volume of $10,000 \mathrm{~m}^{3}$ to be an unit completion water volume, the corresponding production gain will be 1.81 and 1.48 for the Upper Montney 1 and 2 wells in case where job sizes are doubled based on the least squares fitted lines to the relationship (Table 1). Completion water volume and sand volume for the Upper Montney 1 wells in the area 2 have proportional relationship in the study area, thus when doubling the completion water volume, sand volume will be doubled correspondingly (Fig. 6a). The relationship between water volume and completion length (Fig. 6b) shows a scatter because the different stage spacing and completion water/ sand volume per stage were examined for the optimization in the area.

Landing depths of the wells targeting the Upper Montney 1 are in the vicinity of the formation boundary between Montney and Doig phosphate formations but closer to the overlying Doig raising concerns around out of pay-zone (Montney formation) frac growth. However, these concerns are minimized because a linear relationship exists between gas production and job volume (water/sand) which implies major fraction of the effective hydraulic fractures stays in the pay zone even though job size is enhanced (In case where 

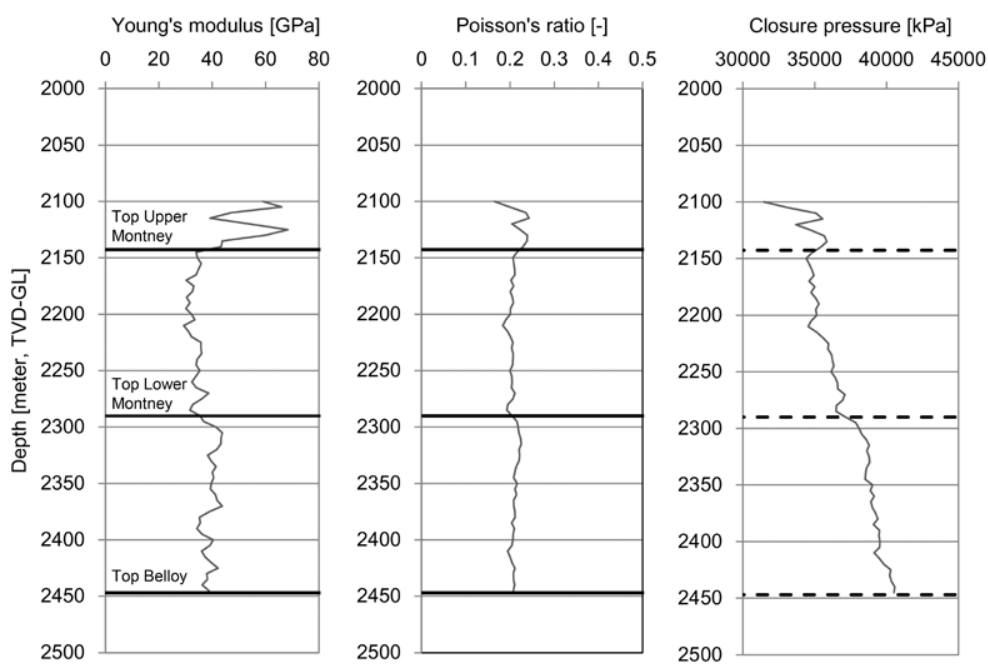

Fig. 8 Elastic moduli and closure pressure profile used for the fracture modeling

(a)

(b)

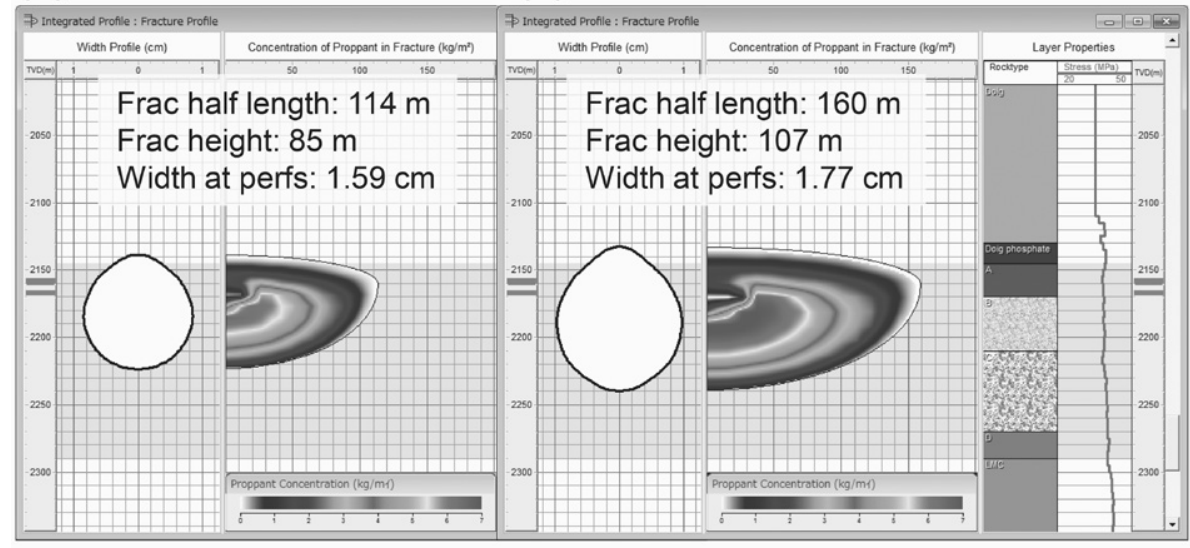

Fig. 9 (a) Fracture geometry modeled with actual fracturing record and (b) the geometry in case the job size is doubled.

fracture extends to the overlying formation with different reservoir characteristics, deviation from the linear relationship is expected in relationship between gas production and job volume). This hydraulic fracture propagation behavior is consistent with the hypothesis that a fracture barrier exists at the top Montney formation preventing fracture propagation toward the overlying formation as mentioned in the next section.

\section{Fracture geometry from microseismic survey}

Microseismic surveys were carried out for the well pad in the study area and hypocenters of the microseismic events were located by selecting events which has distinct $\mathrm{p}$ - and s-wave arrivals in the waveform observed at whole receiver arrays. Fig. 7 shows a vertical cross section highlighting microseismic events during the fracturing jobs implemented at three different target depth of the Upper Montney 1, Mid Montney, and Sexsmith Montney formations.

Almost all of the microseismic events remain within the Montney package between the top of the Upper Montney to the top of the Belloy formation with the exception of a few outliers. Microseismic events revealed three different distinct event propagation behaviors based on landing horizons. In case of the Upper Montney 1, events tended to propagate downward towards the top of Montney D. On the contrary, fractures initiated in the Mid Montney showed an upwards growth behaviour extending towards the top of the Upper Montney and remaining constrained to the top of the Sexsmith Montney below. The Sexsmith well showed a slightly different behaviour with event propagation in both directions yet remaining contained between the Sexsmith and Belloy formations. Based on the fracture propagation behavior at the three different target depths it was inferred potential fracture barriers could exist at the tops of Upper Montney, Montney D, Sexsmith Montney and Belloy which could impede fracture height growth beyond the layers.

\section{Fracture modeling}

Fracture modeling was conducted on one well located in Area 2 landed in the Upper Montney 1 horizon using commercially available modeling software Fracpro (StrataGen, Inc.) and GOHFER (Barree \& Associates LLC). The subject 
Young's modulus

(a)
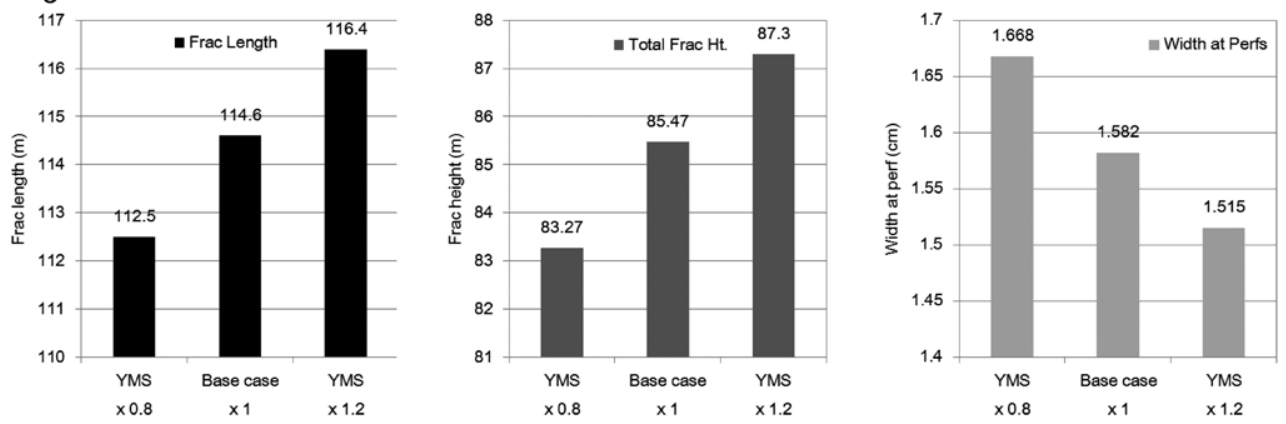

Poisson's ratio

(b)
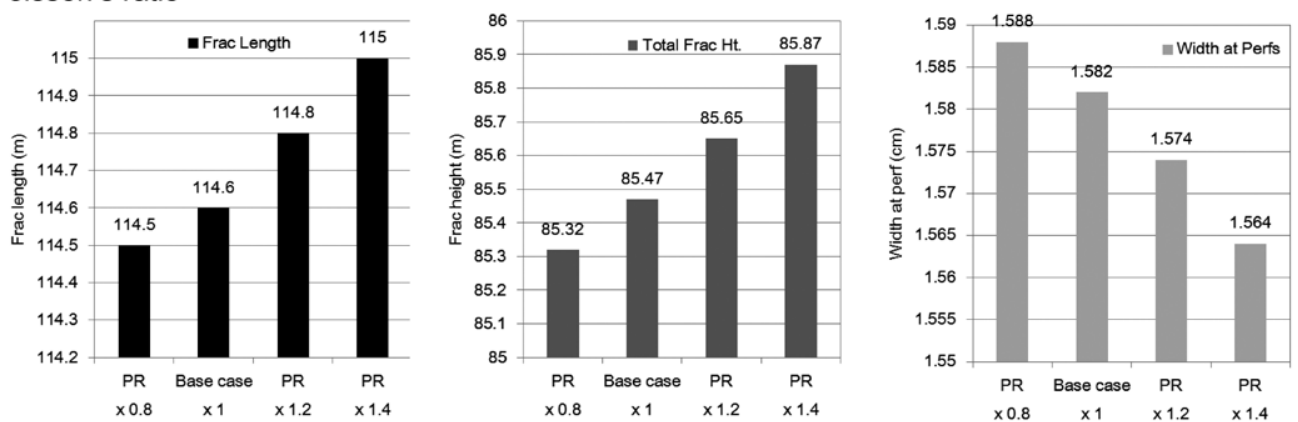

Closure stress

(c)
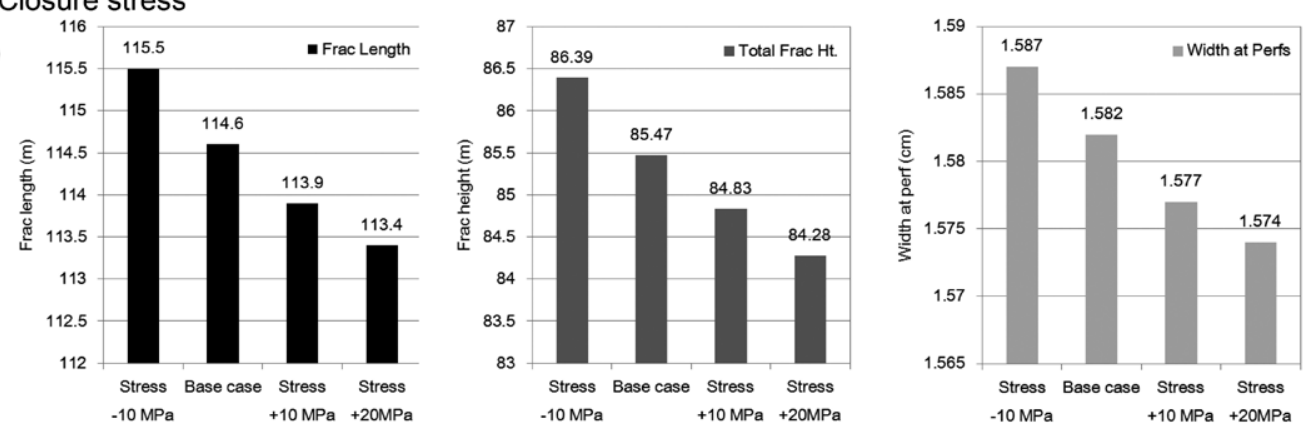

Pore pressure

(d)

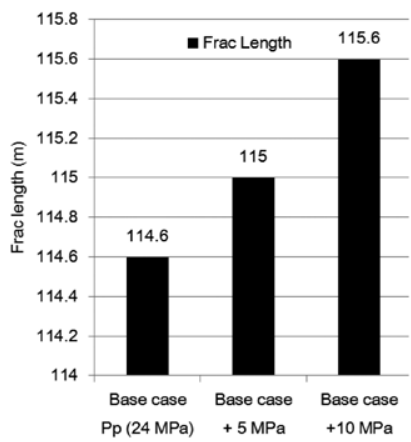

(e) Permeability
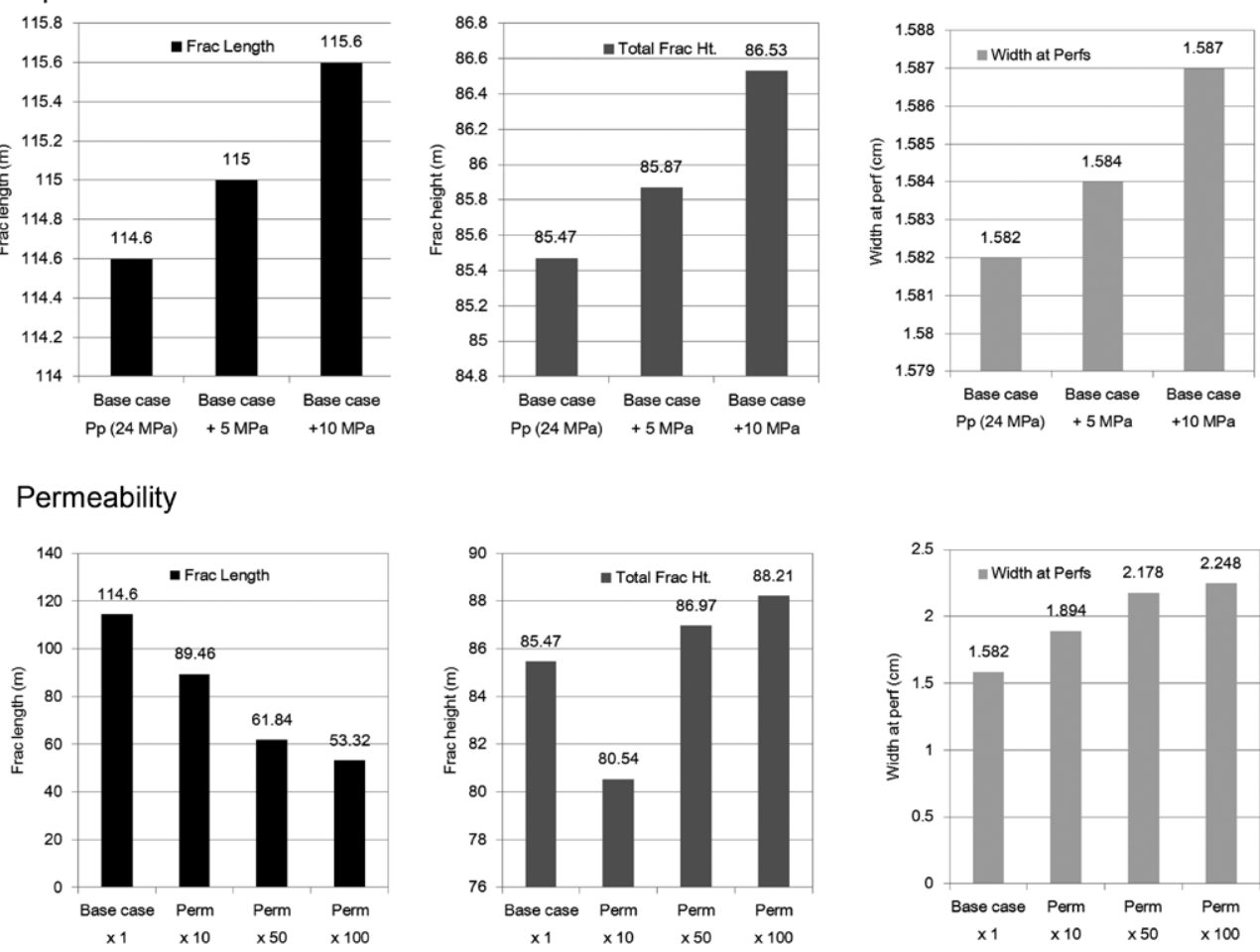
(f)

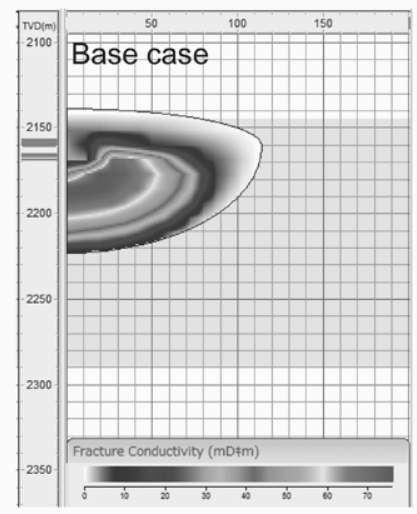

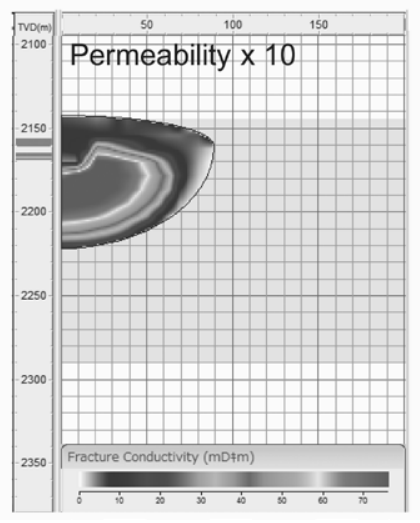

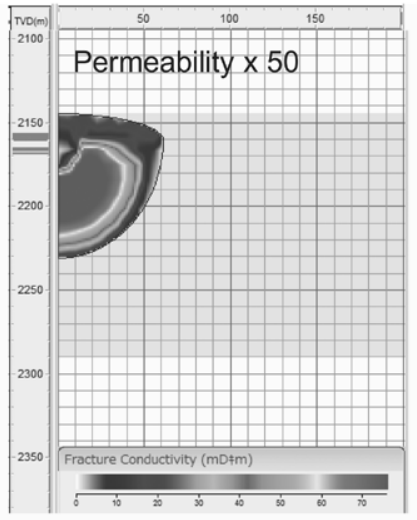

Fig. 10 Effect of (a) Young's modulus, (b) Poisson's ratio, (c) closure stress, (d) Pore pressure (e) permeability on the fracture geometry. (f) 2 dimensional representation of the fracture geometry from base, 10 times and 50 times enhanced permeability cases.

well is a cased hole completed using slickwater limited entry plug and perf technique. Stage spacing is approximately 150 $m$ with 5 clusters per stage. We assume one fracture forms per one cluster in the modeling. While multiple stages were modeled, this study highlighted results for a stage located close to the heel (Stage 10) showing a high degree of confidence around post job history matching attributes and microseismic event data.

Geomechanical and stress models which are fundamental to either one of the models were constructed using wireline $\log$ data and calibrated to laboratory and field test data. The stress regime was determined to be in transition of strikeslip and normal faulting stress regime with NE-SW maximum horizontal principal stress orientation from interpretation of borehole failure analysis. Fig. 8 indicates elastic moduli and closure pressure profile used for fracture modeling. There is an offset in the closure pressure profile near the top of the Lower Montney which may contribute to the fracture containment.

To create the existence of fracture barriers as suggested by the production data review and microseismic survey interpretations, an input parameter named composite layering effect (CLE) was utilized in the Fracpro model. CLE provides the user with an additional parameter that enables hydraulic fracture height growth confinement in addition to those provided by stress and/or permeability contrasts (StrataGen, Inc. 2015). The value reflects the resistance for hydraulic fracture growth through the layer interfaces. High CLE value results in a decrease in the vertical fracture growth. CLE was set to be 100 in this study to reflect the potential fracture barriers and to have net pressure matching at the same time.

Fig. 9a is the fracture geometry of stage number 10 at the well from the model where the net pressure match was achieved with actual job size of $850 \mathrm{~m}^{3}$ clean fluid volume and 200 tons sand per stage. The simulator was run with a job size twice as large as the actual size (Fig. 9b). Fracture geometry was estimated to be $114 \mathrm{~m}$ in half length, $85 \mathrm{~m}$ in height and $1.59 \mathrm{~cm}$ in width at perforation at the end of fracturing job in the actual case. On the contrary, if we double the job size, fracture was evaluated to be $160 \mathrm{~m}$ in half length, $107 \mathrm{~m}$ in height and $1.77 \mathrm{~cm}$ in width at perforation. Based on the modeling result, incremental amount of the fracturing fluid was utilized for the fracture growth and the fracture surface area became 1.76 times. Assuming the high dimensionless fracture conductivity, the increase of the fracture surface area could be a possible explanation for explaining the gain in production observed for the Upper Montney 1 zone in the production data review.

\section{Sensitivity analysis}

Changes in the fracture geometry (half length, height and width at perforation) by adjusting elastic moduli, closure stress, pore pressure, permeability and CLE were investigated to understand the range of possible outcomes (Fig. 10 and Fig. 12). The base case result in the figure shows geometry generated from the net pressure match calibrated to actual pumping data.

Running models with altered elastic moduli of the Young' s modulus (YMS) and the Poisson's ratio (PR) revealed that the fracture length and height increase with elastic moduli, but changes are subtle. Thus it is found that the fracture model is insensitive to the elastic moduli (Fig. 10a and 10b). Change in closure pressure and pore pressure also has subtle effects on fracture geometry. Fracture half-length slightly decreases as the closure stress increases and the half-length slightly increases as the pore pressure increases (Fig. 10c and 10d). Compared to the elastic moduli, closure pressure and pore pressure, permeability has the most noticeable effect on fracture geometry. Smaller and rounded hydraulic fracture formed in the enhanced permeability cases. This would reflect the fracture cannot maintain enough pressure to propagate far from the entry point because of fluid leak-off in the enhanced permeability case (Fig. 10e and 10f).

Prior to discussing the effects of CLE on fracture geometry, let us examine fracture modeling results from a different commercial fracture modeling software, GOHFER. The 


\section{Total stress map}

(a)

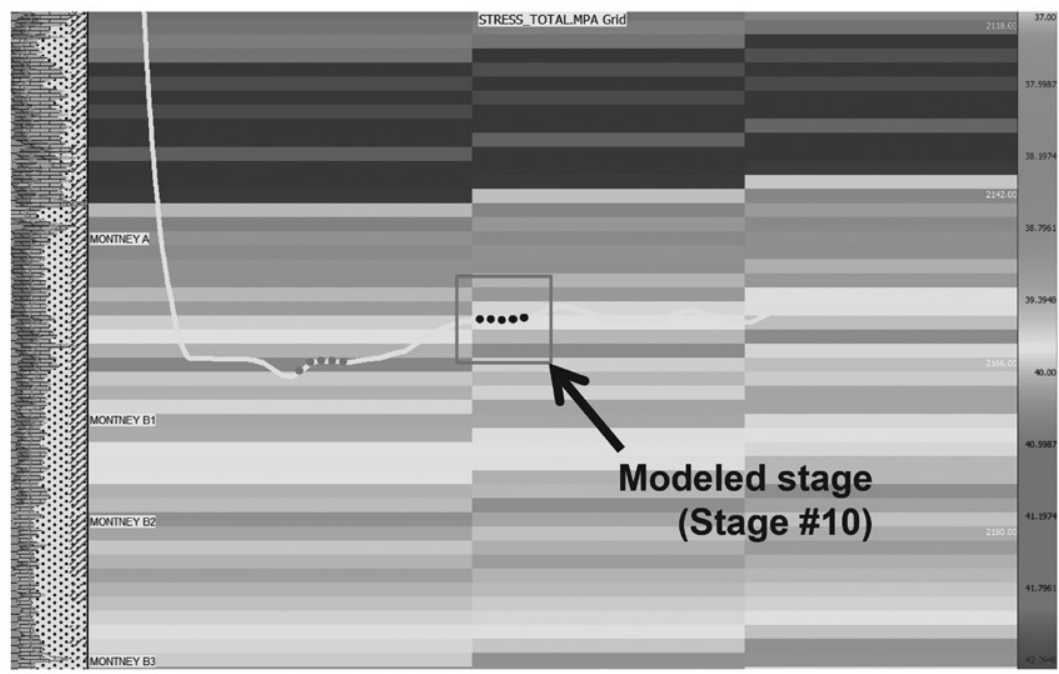

(b)

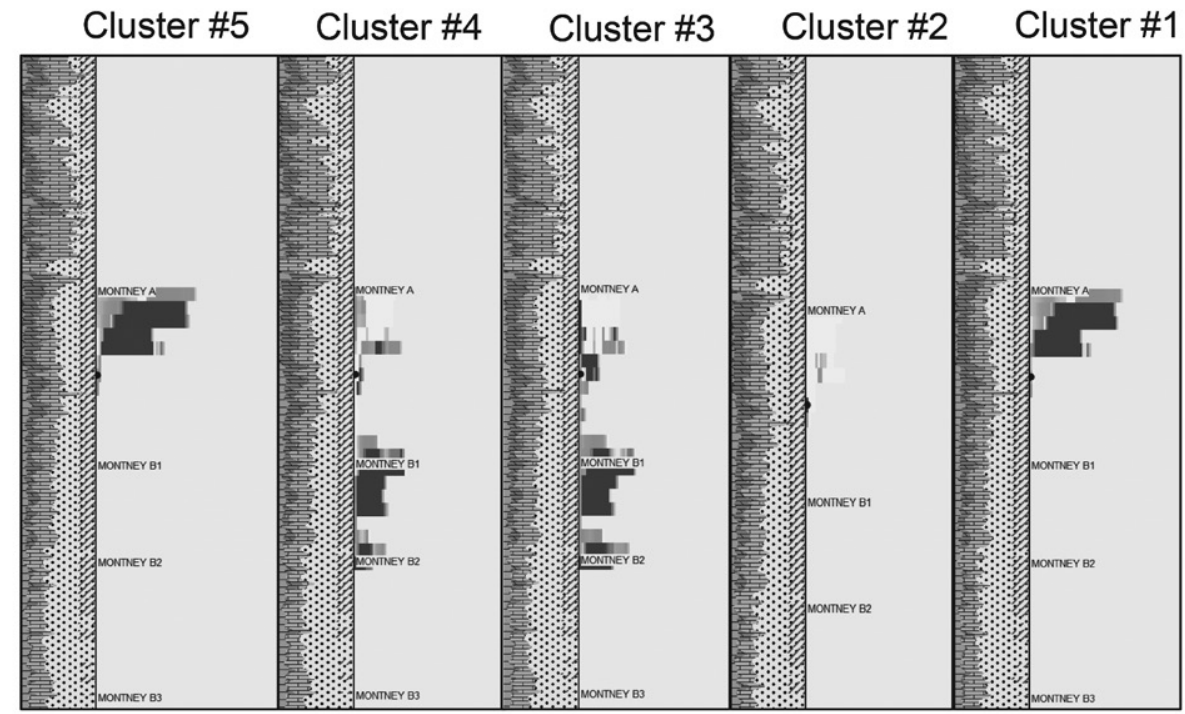

Fig. 11 (a) Total stress map with well trajectory. (b) Fracture geometry modeled for the same stage (stage 10) by GOHFER.

(a)

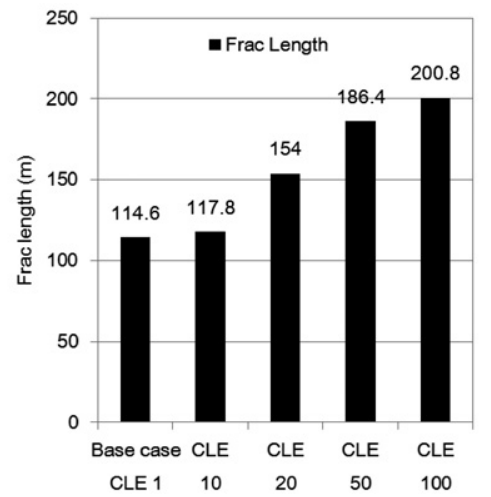

(b)
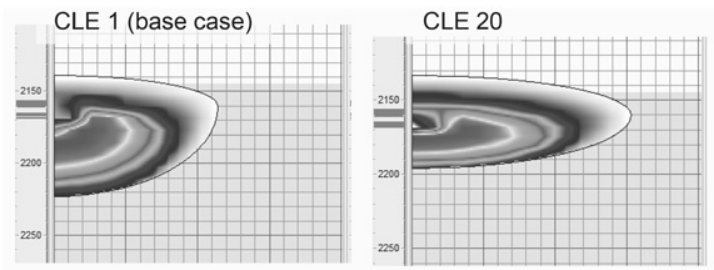

Fig. 12 (a) Change in Fracture geometry by CLE. (b) 2 dimensional representation of the fracture. 
post job history matched fracture geometry obtained from GOHFER for Stage 10 is shown in Fig. 11. Entry points are indicated by black dots both in the total stress map (Fig. 11a) and a cross sectional view indicating of the fracture geometry is displayed in Fig. 11b.

Since the simulator honors changes in stress and rock fabric while taking into account stress shadowing effects, fracture geometries vary by cluster. There are high total stress layers below the entry points which influences propagation behaviour of each cluster in the stage. Clusters 1 and 5 are likely to propagate in the upward direction. Clusters 3 and 4 show a tendency to grow higher than cluster 1 and 5 but are likely to propagate downward and away from the stress layers. Cluster 2 shows poor development likely due to stress shadowing effects. Fracture geometries from the GOHFER model suggest a frac height range of 16 to $42 \mathrm{~m}$ and a proppant cut-off half-length of 50 to $240 \mathrm{~m}$.

To gain consistency between the two models, sensitivities were run, using the CLE feature in Fracpro. CLE values were adjusted to mimic the fracture containment suggested by the GOHFER model due to high total stress layers below the entry points. When CLE at the layers is increased, the fracture geometry will exhibit a longer half-length and smaller frac height. When we set the CLE value of 100 for the layers, the geometry generated in Fracpro is comparable to that from GOHFER modeling (Fig. 12). This agreement in the fracture geometry would reflect mass conservation of the fracturing fluid within the formation.

\section{Summary}

To obtain insights to optimize the fracture design, attempts were made to envisage fracture propagation behavior in the Upper Montney formation for the study area located in the Northern part of Dawson Creek. Microseismic survey results taken for pad wells landing different target depths revealed that there are several fracture barriers in the Montney formations which could impede vertical fracture growth. In the study area, wells are completed using varying job sizes and completion volume. Production analysis suggests that gas production has a linear relationship with completion volume. Gradient of the least squares fitted line to the data are also shown to have different magnitudes which vary by target zone. This approach suggests that wells completed in Upper Montney 1 have a production increase of 1.81 times by doubling completion volume. Due to the linear relationship in gas production and the completion volume, it is suggested that hydraulic fractures do not propagate into the overlying Doig Phosphate formation and remain in the Montney pay zone for all wells targeting the Upper Montney 1 where the entry points are close to the formation boundary.

Fracture modeling for an Upper Montney 1 well has suggested that surface area created by doubling completion volume is 1.76 times larger than the base case. Increases in the surface area is the possible explanation for improvements in gas productivity found in the zone. Contacting the reservoir with a larger surface area also increases the likelihood of connecting with an potential enhanced permeability region in the area however the impact on productivity is beyond the scope of this study. In addition to frac size, there are numerous other parameters which are key for completion optimization and should be addressed in future works.

\section{Acknowledgements}

This work were carried out through the collaboration research with Encana Corporation and Mitsubishi Corporation. We would like to express our thanks for them to give us the opportunity to present the results of the research. We also thank Isao Kurosawa at JOGMEC for sharing results of the microseismic survey.

\section{References}

Davies, G.R., Moslow, T.F. and Sherwin, M.D., 1997 : The Lower Triassic Montney Formation, west-central Alberta. Bulletin of Canadian Petroleum Geology, 45 (4) , 474-505. StrataGen, Inc., 2015 : Fracpro manual.

$$
\begin{gathered}
\text { モントニータイトサンドプレイにおける水圧破砕 } \\
\text { 最適化の取り組み }
\end{gathered}
$$

関根孝太郎・チャンドレッシュ シン・原＼cjkstart祥二

エンカナ社は過去十数年にわたりさまざまな水圧破砕技 術を適用することで, 非在来型ガスプレイであるモント ニータイトレザバーの開発に成功してきた。水圧破砕ジョ ブのデザインによって, 生産量は大きく変化するため, そ の最適化は開発における経済性に大きなインパクトがあ る。そこで本稿では, 上部モントニー層における水圧破砕 き裂の伸展挙動を支配するいくつかの因子について概説す る。商用モデリングソフトウェアを用いた水圧破砕き裂の モデリングやマイクロサイスミックのモニタリング結果に 基づき, 水圧破砕き裂のジオメトリーやその伸展挙動を評 価した。弾性定数, き裂閉口圧, 地層圧, 岩石組織に対す るモデルの感度評価により, 水圧破砕き裂のジオメトリー の取り得る範囲を検討した。その結果, モントニー層にお いて垂直方向の水圧破砕き裂の伸展を妨げるいくつかのバ リアーの存在が示唆された。特定のエリアに位置する井戸 の生産量と水圧破砕ジョブの大きさを比較したところ, 累 積生産量と水圧破砕で圧入した流体量に正の線形関係が認 められた。また, その傾きはターゲット層により異なるこ とが明らかとなった。水圧破砕ジョブの大きさを 2 倍にす ると, ガス生産量が 1.81 倍に増加する。このような生産 量の増加は, 水圧破砕き裂の表面積増加によって説明でき ることが示唆された。 